\title{
VIRTUES, WORK EXPERIENCES, SATISFACTIONS AND WELL-BEING AMONG PHYSICIANS IN TURKEY ${ }^{1}$
}

\author{
MUSTAFA KOYUNCU \\ Nevşehir University \\ RONALD J. BURKE \\ Prof.Dr.,York University \\ LISA FIKSENBAUM \\ Prof.Dr.,York University
}

\begin{abstract}
This study examined the relationship between virtues and indicators of work satisfaction and engagement, extra-work satisfactions and psychological wellbeing among physicians. Data were collected from 431 physicians in Turkey using anonymously completed questionnaires. A virtue is any psychological process that enables a person to benefit him or herself and others. Three virtues were considered: gratitude, optimism, and proactive behaviors. This emphasis was consistent with emerging trends in both psychology and organizational studies, termed positive psychology or positive organizational scholarship respectively, to focus on strengths and excellence rather an weakness and pathology. Hierarchical regression analyses, controlling for both personal demographic and work situation characteristics, indicated that virtues accounted for significant increments in explained variance on most outcome measures. Optimism emerged as a particularly consistent predictor of most outcomes. Explanations for the association of virtues with favorable outcomes are offered along with potentially practical implications.
\end{abstract}

Keywords: Work Experiences, Well-Being, Work satisfaction and engagement, Physicians, Turkey

\footnotetext{
${ }^{1}$ Preparation of this manuscript was supported in part by York University and Nevsehir University. We acknowledge the cooperation of our respondents.
} 
Individuals' rate health care as one of their most important priorities in many countries and it is likely to become even more important as populations age. In response to this need, governments devote significant amounts of their budgets to funding the health case system, this allocation typically being the largest budget item in almost all countries. Increases in funding for health care have also generally risen faster than inflation rates highlighting both the importance and costs of health care.

Doctors occupy a central role in the delivery of health care though countries may have different health care systems and methods of payment options to their doctors. Some countries report an increasing shortage of doctors, often compounded by the fact that richer nations can lure doctors away from poorer ones. The health care system has also undergone significant changes over the past decade stemming from the greater use of new technologies, off-shoring some services to developing countries, advances in medical knowledge, an aging population, more informed and critical users of the health care system, and efforts by governments to control health care expenditures.

It is not surprising then that that considerable research has been undertaken to understand the work experiences of doctors, particularly as they relate to physician satisfaction and well-being and patient care. Almost all of this work has used a stressor-strain framework. It has concentrated on issues of workload, lack of resources, long work hours, increasingly more difficult patients, threats of litigation, and administrative duties, as these affect burnout, depression, psychosomatic symptoms, and dissatisfaction with the profession. This work has contributed a great deal to our understanding of the experiences of physicians in their workplaces. These are all important topics for research but they tell only half the story.

An emphasis on these negative experiences and outcomes is consistent with the past sixty years in the field of psychology with its emphasis on pathology and illness, and the past forty years in the fields of organizational behavior and management with their emphasis on concepts such as job dissatisfaction, withdrawal behaviors, work family conflict and alienation in the workplace-an emphasis on "what is wrong" in organizations.. Recent developments in these fields, however, have fostered a different emphasis; an emphasis on human flourishing and individual strengths represented by the beginnings of positive psychology (Seligman \& Csikszentmihalyi, 2000) and what is right" in organizations represented by positive organizational scholarship (Cameron, Dutton \& Quinn, 2003) and positive organizational behavior 
(Luthans, 2002). Positive psychology and positive organizational scholarship focus on positive outcomes such as meaning, engagement, resilience, thriving and organizational excellence -the best of human and work conditions.

This study examines stable individual difference traits termed virtues and the work experiences, work and extra-work satisfactions and psychological well-being of physicians in Turkey. Although some research has examined work experiences and health among Turkish physicians (Ozyurt, Hayran \& Sur, 2006), the role of virtues in the experiences of physicians in Turkey have not been previously examined to our knowledge. We will set the stage for our research by providing a selective review of literature relating to (1) physicians and health care in Turkey, (2) work experiences and health of physicians, and (3) virtues and individual and organizational well-being..

\section{Physicians and health care in Turkey}

According to the Organization for Economic Cooperation and Development (OECD), based on 2007 data, Turkey ranks low on health spending falling below the average across all OECD countries based on share of Gross Domestic Product expenditures per capita; the US spending the most, followed by Switzerland, France and Germany. Most of the funding for health care in Turkey comes from the government or public sector. Turkey is now, however, increasing health care spending above the OECD average. Turkey has fewer doctors and nurses per capita than other OECD countries. Life expectancy in Turkey is still below the OECD average. Infant mortality rates are higher in Turkey, as are rates of smoking, but rates of obesity are lower. The Turkish health care system is currently undergoing change, as is the case in many other countries.

\section{Work and health of physicians}

Much of the research examining physicians has considered the relationship of work experiences, job stress and psychological wellbeing (Burke, 1990; 1996). Cooper, Rout and Faragher (1989, in a sample of1817 general practitioners in the UK, found that four job stressors were predictive of high levels of job dissatisfaction and lack of psychological well-being: demands of the job and patient' expectations, interference with family life, constant interruptions at work and home and administrative duties. 
A number of other researchers have examined work experiences, stress and well-being among physicians. Chambers, Wall and Campbell (1996) considered stresses, coping and job satisfaction in general practitioner registrars; Golub, Weiss, Ramesh, Ossoff and Johns (2007) studied burnout in US residents in otolaryngology-head and neck surgery; Garza, Schneider, Promecene and Monga (2004) considered burnout of residents in obstetrics and gynecology; and Burbeck, Coomber, Robinson and Todd (2002) considered occupational stress in consultants in accident and emergency medicine.

Richardson and Burke (1991), in a large sample of Canadian female and male physicians, reported that for both female and male physicians, high levels of occupational stress were associated with less job satisfaction and satisfaction with medical practice and more negative attitudes about the Canadian Medicare system and health care in general, and high job satisfaction was related to fewer specific work stressors and more positive attitudes about the health care system.

Rout and Rout (1994) compared measures of job satisfaction, psychological well-being and job stress among general practitioners in the UK before and after the introduction of a new government-physician contract. Data were collected in 1987 and again 1993 from 380 physicians. Physicians reported higher levels of job dissatisfaction psychological distress and more stress in 1993 than in 1987. The new contract heightened stress, dissatisfaction and distress. Sutherland and Cooper (1992) reported similar increases in dissatisfaction, psychological distress and job stressors following introduction of the new contract in 1990 in the UK in a sample of 917 general practitioners. Appleton, House and Dowell (1998) reported significant increases in mental distress following the new contract in a study of 285 general practitioners, along with decreases in job satisfaction. Their respondents also believed that their work had a negative effect of their physical health. Job stress and dissatisfaction seems to be increasing among general practitioners in the UK, and elsewhere (e.g., for Canada, see Burke, 1996; for Germany, see Janus, Amelung, Gaitanides \& Schwartz, 2007; for the US, see Murray, Montgomery, Chang, Rogers, Inui \& Safran, 2001)

In summary, much of the research on physicians has utilized a stressor -strain paradigm. Physicians work long hours and experience high levels of work-family conflict. They are concerned about patient expectations, litigation from malpractice, and increasing amounts of paperwork. There is also accumulating evidence that physician dissatisfaction with their work and their profession has increased over 
the past 20 years in several developed countries. But physicians tend to be generally satisfied with their relationship with their patients and with their commitment to improving patient well-being.

\section{Virtues and Individual and Organizational Well-Being}

The present study examines stable individual traits termed "virtues" in the work experiences, satisfactions and well-being of physicians. Virtues have been discussed by philosophers for almost 2000 years. A virtue is defined by McCullough and Snyder (2000) as "any psychological process that enables a person to think and act so as to benefit both him or her and society (p. 1). A virtue is "a discrete organized system of thought, reason, emotion, motivation and action" (McCullough \& Snyder, 2000, p. 3). Character, to them, is a higher order concept that encompasses the possession of several virtues. Virtues are making resurgence as a topic of study in both psychology and positive organizational scholarship. Virtues benefit individuals, other people, and society more broadly. It is somewhat surprising that virtues have not been studied among physicians given their commitment to improving human health and well-being. The neglect of virtues also has had potentially important consequences. These include the separation of individuals from the wider social and external context of their actions, making it difficult to identify traits that contribute to our understanding of human flourishing, and making it hard to suggest virtue-based solutions to various problems.

This study included three virtues: optimism, gratitude and proactive or transcendent behavior.

\section{Optimism}

Peterson (2000) reviews research on optimism, a stable trait or individual difference variable, showing it to be related to good mood, perseverance, achievement and physical health. Optimism is an attitude or belief that one's future will be positive and satisfying. Scheier and Carver (1992) view optimism as a personal disposition associated with the expectation that good things will be common in the future. Optimism has cognitive, emotional and motivational components.

Optimism has been found to be related to good morale, effective problem solving, success in various endeavors (e.g., academic, athletic, military, occupational, political) and to longevity (see Peterson, 2000; Seligman, 1991; Scheier \& Carver, 1985, 1987; 1992). 


\section{Gratitude}

Emmons and Crumpler (2000) examined the research literature on the virtue of gratitude. Gratitude involves feeling grateful for positive outcomes one had experienced; it is an emotional state and an attitude toward life. Gratitude has been found to be associated with life satisfaction and fewer physical health complaints (Emmons \& McCullough, 2003), positive emotions (Walker \& Pitts, 1996)k, and happiness, pride and hope (Overwalle, Mervielde and de Schuyter, 1995). Emmons and McCullough (2003) report findings from three studies of gratitude or grateful thinking (a grateful outlook) and psychological and social functioning. The grateful outlook groups indicated higher levels of well being across most of their outcome measures.

\section{Proactive Behavior}

Almost all experts on the workplace agree that employees should be more proactive on the job and that proactive behavior increases job performance. Crant (2000) considered antecedents and consequences of proactive behavior in organizations. Bateman and Crant (1993) have undertaken research on proactive behavior or the proactive personality. Proactive people identify opportunities and act on them, take initiative, and persevere until goals are reached or change is successfully achieved. Crant (2000) reviewed research findings showing that proactive real estate agents were more productive (Crant, 1995), those managers and professionals scoring higher on proactive behavior were more successful in heir careers on a number of dimensions (Seibert, Crant \& Kraimer, 1999), more proactive behaving individuals were more likely to display leadership (Crant \& Bateman, 2000), more proactive individ9als were more likely to see their work roles in broader terms and undertake more performance-related initiatives (Parker, 1998), students were more likely to intend to start their own businesses (Crant, 1996) , proactive individuals were more likely to improve sales in small companies (Becherer \& Maurer, 1999), and at a team-level, team-level proactivity was correlated with productivity levels, customer service quality, job satisfaction, organizational commitment and team commitment (Kirkman \& Rosen, 1999).

The present study examined the relationship of virtues -positive stable traits - and physician work experiences, satisfactions and psychological well-being. It provided $\mathrm{n}$ examination of the general 
hypothesis that virtues would be associated with more favorable work and well-being outcomes (Cameron, Dutton \& Quinn, 2003.

\section{Method}

\section{Respondents}

Table 1 (Table 1) presents the demographic characteristics of the sample. The sample had slightly more males than females $(55 \%)$, were forty years of age of younger $(69 \%)$, slightly more than half were married $(56 \%)$, most had one or two children $(60 \%)$, most worked in large cities (greater than 500,000, 49\%), worked in medium-sized hospitals (125 to 400 beds, 65\%), worked in group practices $(70 \%)$, earned between US 12,000-US $26 \mathrm{~m} 000$ (64\%), had less than 10 years of professional, job and hospital tenure $(63 \%, 65 \%$, and $87 \%)$ respectively), and worked between $41-60$ hours per week (79\%)

\section{Procedure}

Data were collected from 431 physicians using anonymously completed questionnaires. Questionnaires were sent to about 1800 physicians working in three Turkish cities (Nevsehir, Nigde and Kayseri). Thirty-nine were returned incomplete giving a response rate of twenty-six percent. The names of physicians were obtained from the Directorate of Health and excluded Residents. This response rate is typical of studies of physicians, an occupation characterized by heavy workloads and paper-work.

\section{Measures}

All measures were translated from English to Turkish using the back translation method.

\section{Personal Demographics}

Individual demographic characteristics were measured by single items and included: age, sex, marital status, number of children, and income.

\section{Work Situation Characteristics}

Several work situation characteristics, also measured by single items, were included. The were : size of community in which they worked, years in present position, years in present hospital, years in profession, size of hospital, main form of payment, and hours worked per week.

\section{Virtues}

Three virtues were included. 
Proactive personality was measured by a seventeen item scale $(\alpha=.93)$ developed by Bateman and Crant (1993). Respondents indicated their agreement with each item on a seven-point Likert scale (1=strongly disagree, 4=neither agree nor disagree, 7=strongly agree). An item was" I am good at turning problems into opportunities."

Optimism was measured by an eight item scale $(\alpha=.81)$ developed by Scheier and Carver $(1985,1987)$. One item was "In uncertain times, I usually expect the best". Respondents indicated their agreement with each item on a five-point Likert scale.

Gratefulness was assessed by a six item scale ( $\alpha=.71)$ developed by McCullough, Emmons and Tsang (2002) and Emmons and McCullough (2003). One item was "I have so much in my life to be thankful for." Respondents indicated their agreement with each item on a seven point Likert scale (1=strongly disagree, $4=$ neutral, $7=$ strongly agree).

\section{Work Outcomes}

Job satisfaction $(\alpha=.92)$ was measured by a seven item scale developed by Kofodimos (1993). An item was "I feel challenged by my work."

Career satisfaction was measured by a four item scale $(\alpha=.890)$ developed by Greenhaus, Parasuraman and Wormley (1990). One item was "I am satisfied with the success I have achieved in my career."

Intent to quit $(\alpha=.69)$ was measured by two items (e.g.., "Are you currently looking for different job in a different organization?) This scale had been used previously by Burke (1991).

Absenteeism was measured by a two item scale $(\alpha=.75)$. One item was"How many days of scheduled work have you missed in the past month?"

\section{Work Engagement}

Three aspects of work engagement were measured using scales developed by Schaufeli, et. al. (2002) and Schaufeli and Bakker (2004) Respondents indicted their agreement with each item on a five-point Likert scale (1=strongly disagree, $3=$ neither agree nor disagree, $5=$ strongly agree).

Vigor was measure by six items $(\alpha=.94)$ "At my work I feel bursting with energy." 
Dedication was measured by five items $(\alpha=.92)$. "I am proud of the work that I do."

Absorption was measured by six items ( $\alpha=.81)$. "I am immersed in my work."

\section{Extra-work satisfactions}

Three aspects of life or extra work satisfaction were included.

Family satisfaction was measures by a seven item scale $(\alpha=.64)$ developed by Kofodimos (1993). One item was "I have a good relationship with my family members."

Friends satisfaction was measured by three items $(\alpha=.69)$ also developed by Kofodimos (1993). An item was "My friends and I do enjoyable things together."

Community satisfaction was measured by four items $(\alpha=.69)$ again developed by Kofodimos (1993). A sample item was "I contribute and give back to me community."

\section{Quality of Life and Psychological Well-Being}

Three aspects of psychological well-being were included: workfamily and family-work conflict, psychosomatic symptoms and life satisfaction.

\section{Work-family and Family-work conflict}

Work-family and family-work conflict were each measured by five item scales developed by Carlson, Kacmar and Williams (2000). One item for the Work-family conflict scale $(\alpha=.94)$ was "The demands of my work interfere with my home and family life"; an item on the Family-work conflict scale $(\alpha=.92)$ was "I have to put off doing things at work because of demands on my time at home".

Psychosomatic symptoms was measured by nineteen items $(\alpha=.88)$ developed by Quinn and Shepard (1974). Respondents indicated how often they experienced each physical condition (e.g., "headaches") in the past year.

Life satisfaction was measured by five items $(\alpha=.93)$ developed by Diener, Emmons, Larsen and Griffin (1985). One item was "In most ways, my life is close to ideal". Respondents indicated their agreement with each item on a five point Likert scale 


\section{Results}

\section{Inter-correlations among virtues}

All three correlations between the three virtues were positive and significantly different from zero $(p<.001)$ : optimism and gratitude $(r=.79)$, optimism and proactive behavior $(r=.70)$, and gratitude and proactive behavior $(r=.76)$. Thus these three virtues represented correlated strengths in this sample of physicians.

\section{Hierarchical Regression Analyses}

Hierarchical regression analyses were undertaken in which various work outcomes and indicators of psychological well-being were regressed on three blocks of predictors entered in a specified order. The first block of predictors $(n=5)$ consisted of personal demographics (e.g., age, marital status, parental status); the second block $(n=6)$ consisted of work situation characteristics (e.g., position tenure, hospital tenure, hospital size, type of practice); the third block of predictors $(n=3)$ consisted of the virtues (e.g., gratitude, optimism, proactive behavior). When a block of predictors accounted for a significant amount or increment in explained variance $((p<.05)$, individual variables within these blocks having significant and independent relationships with the criterion variable $(p<.05)$ were identified. These significant and independent relationships are shown in the tables that follow along with their Bs

\section{Virtues and Work Outcomes}

Table 2 (Table 2) presents the results of hierarchical regression analyses in which four work outcomes were separately regressed on the three blocks of predictors: personal demographics, work situation characteristics and virtues. The following comments are offered in summary. First, personal demographics accounted for a significant amount of explained variance on three of the four work outcomes (not intent to quit); but only one measures within this block had a significant and independent relationship with a work outcome. Physicians with fewer children indicated more career satisfaction. Second, work situation characteristics accounted for a significant increment in explained variance on only one of the four work outcomes (job satisfaction); physicians having hospital privileges indicated higher levels of job satisfaction. Third, Virtues accounted for a significant increment in explained variance on all four work outcomes. Physicians indicating higher levels of optimism also reported more job satisfaction, more career satisfaction and less intent to quit; physicians indicating 
more proactive behavior, and physicians indicating more gratitude, also reported higher levels of job satisfaction.

\section{Virtues and Work Engagement}

Table 3 (Table 3 ) shows the results of regression analyses in which three measures of engagement were separately regressed on the three blocks of predictors. Personal demographics accounted for a significant amount of explained variance in all analyses. But no single measure within this block had a significant and independent relationship with engagement. Work situation characteristics also accounted for a significant increment in explained variance on all engagement measures. Physicians working in smaller hospitals reported higher levels of vigor; physicians working in solo practices, and physicians having hospital privileges, indicated higher levels of absorption. Virtues also accounted for a significant increment in explained variance on all indicators of engagement, and all three virtues had significant and independent relationships with each measure of engagement.

\section{Virtues and Extra-Work Satisfactions}

Table 4 (Table 4) presents the results of hierarchical regression analyses in which three measures of extra-work satisfaction (family, friends, community) were separately regressed on the three blocks of predictors. Personal demographics accounted for a significant amount of explained variance on two of three extra-work satisfactions (family, community). Physicians having more children, physicians that were married, and physicians working in larger communities indicated more family satisfaction; and male physicians also indicated more community satisfaction. Work situations characteristics also accounted for a significant increment in explained variance on two extra-work satisfactions: friends and community. Physicians working in larger hospitals, and physicians having less job tenure, indicated more friends' satisfaction. Finally, virtues accounted for a significant increment in explained variance on all three extra-work satisfactions. Physicians reporting higher levels of optimism also indicated more extra-work satisfaction on all three measures; physicians indicating more gratitude also reported higher levels of family satisfaction; and physicians reporting higher levels of proactive behavior also indicated more community satisfaction. 


\section{Virtues, Quality of Life and Psychological Well-Being}

Table 5 (Table 5 ) shows the results of hierarchical regression analyses in which three quality of life indicators (work-family conflict, family-work conflict, life satisfaction) and one psychological well-being indicator (psychosomatic symptoms) were regressed on the three blocks of predictors. The following comments are offered in summary. First, Personal demographics accounted for a significant amount of explained variance on the three quality of life indicators but not on the measure of psychosomatic symptoms. Older physicians indicated less work-family and family -work conflict but also lower levels of life satisfaction; married physicians indicated less work-family conflict and higher levels of life satisfaction; physicians having more children were more satisfied with their lives; and physicians working in larger communities were also more satisfied with their lives. Second, work situation characteristics accounted for a significant increment in explained variance on two of the three quality of life indicators (workfamily and family-work conflict) and on the measure of psychosomatic symptomatology. Physicians working in group practices reported more work-family conflict; physicians working in larger hospitals, physicians without hospital privileges, and physicians having less job tenure reported higher levels of family-work conflict; and physicians having less job tenure, and physicians not having hospital privileges, indicated more psychosomatic symptoms. Third, virtues accounted for a significant increment in explained variance on three of the four measures familywork conflict, life satisfaction, and psychosomatic symptoms. Physicians indicating higher levels of optimism indicated lower levels of family-work conflict while those indicating more proactive behavior indicated higher levels of family-work conflict. Physicians scoring higher on each of the three virtues indicated greater life satisfaction. And physicians indicating more gratitude reported lower levels of psychosomatic symptoms.

Let us now draw some conclusions across all the analyses that were undertaken. First, personal demographics accounted for a significant amount of explained variance in over three quarters of these analyses but explained relatively small amounts of variance. In addition, different personal characteristics produced significant and independent relationship with these outcomes; there were no consistent relationships. Second, while work situation characteristics also accounted for significant increments in explained variance in a majority of the analyses, they too accounted for a small amount of explained 
variance and also produced inconsistent relationships. Third, virtues also accounted for a significant increment in explained variance on most work and well-being indicators, but they accounted for a large amount of explained variance, and one virtue -optimism - had a significant and independent relationship with work and well-being indicators in many of the analyses (see Tables 2 through 4).

\section{Discussion}

This study provided preliminary support for the general hypothesis underlying the research. That is, physicians reporting higher levels of virtues would $b$ e more satisfied and engaged at work, would indicate greater extra-work satisfactions, and report higher levels of life quality and psychological well-being. These results wee supportive of previous theorizing (see Cameron, Dutton \& Quinn, 2003; Luthans, Youssef \& Avolio, 2007; Nelson \& Cooper, 2007; Snyder \& Lopez, 2002) and consistent with empirical findings (Bakker, 2008; Luthans, Avey, Avolio, Norman \& Combs, 2006; Luthans, Avolio, Avey \& Norman, 2007). Thus virtues seem to be associated with greater satisfaction and extra-work satisfaction and better individual health.

\section{Why are virtues associated with positive outcomes?}

Four different explanations for the association of virtues with higher levels of individual and organizational well-being have been proposed. First, virtues, as reported above, were associated with positive emotions. In addition, virtues tend to be associated with other virtues, increasing the experiencing of positive emotions even more (Carver, 1998). Individuals experiencing positive emotions are more likely to be proactive, to engage in organizational citizenship behaviors, be outgoing, and think and act in more creative ways. Fredrickson (2001; 2003) developed her "broaden-and-build" theory of positive emotions which, at its core, suggests that positive emotions foster an upward spiral of individual functioning (See Fredrickson \& Branigan, 2005).

Second, virtues are associated with higher levels of individual psychological and physical health. Healthy individuals are likely to bring heightened focus, vigor and persistence, which in turn contribute to higher levels of individual and organizational functioning (see Fredrickson \& Joiner, 2002; Ryan \& Frederick, 1997; Shirom, 2003).

Third, virtues are associated with increases in both personal and job or organizational resources over time. This would be predicted by Fredrickson's "broaden-and-build" theory; the rich keep getting richer. Particular virtues are likely to increase over time, land the 
consequences of these virtues (e.g., proactive behavior, creativity, vigor) are also likely to increase over time resulting in more personal resources. In addition, virtues would also be associated with more job and organizational resources over time as well (e.g., more variety, more feedback and learning). Virtues can make it make it easier for individuals to bounce back after setbacks in their personal or work lives (Tugade \& Fredrickson, 2004; Youssef \& Luthans, 2007).

Fourth, virtues have also been found to influence colleagues in the workplace; virtues can be transferred to others. To the extent to which this occurs, the unit or organization becomes stronger and more effective. Positive emotions can be transferred to colleagues and customers (See Bakker, 2008; Baker, Cross \& Wooten, 2003; Fredrickson \& Losada, 2005).

\section{Can virtues be developed?}

There have been some efforts to develop individual virtues that appear to have been successful. Emmons and McCullough (2003), in studies with university students, developed gratitude by having them "count their blessings", that is, write down up to five things in their lives over the past week that they were grateful or thankful for; this was repeated over several weeks. Bakker (2008) describes his work with individuals and their employing organizations to increase engagement using both individual interviews and survey data feedback. Seligman (1998) lays out his program for increasing optimism. Brown and Ryan (2001) show how their efforts to develop mindfulness among cancer patients resulted in both increased mindfulness over time and declines in mood disturbances and stress. Eisenberger (1992) suggests how learned industriousness can be increased. Snyder (1994; 1995) illustrates ways $\mathrm{n}$ which hope can be heightened. Finally, Luthans and his colleagues (Luthans, Avey, Avolio, Norman \& Combs, 2006; Luthans, Avolio, Avey \& Norman, 2007; Luthans, Vogelgesang \& Lester, 2006; Luthans, Youssef \& Avolio, 2007) describe a microintervention in some detail that they have used to increase levels of Psychological Capital (i.e., hope, optimism, resilience). Taken together, these efforts provide a solid basis for further initiatives to increase virtues.

\section{Limitations of the study}

Some limitations of this study should be acknowledged to put the findings in a broader context. First, though the sample was large and the response rate fairly high, it was not possible to determine the representativeness of the sample. Second, all measures were based 
on respondent self-reports raising the possibility of common method variance. Third, a few of the measures had internal consistency reliabilities below the typically accepted level of .70. Fourth, many of the work and extra-work outcomes were themselves moderately correlated. Fifth, since the data were collected at one point in time it was not possible to examine the issues of causality. Finally, it is not clear the extent to which our findings generalize to physicians working under different fee arrangements or in other cultures and countries.

\section{Future research directions}

Our understanding of the work experiences, satisfactions and health of female and male physicians would be increased by incorporating additional virtues in future research (e.g.,, resilience, hope, mindfulness). Second, the use of objective indicators of both absenteeism and psychological and physical health obtained from hospital records or independent sources would complement self-report questionnaire data. Third, the use of longitudinal research designs would permit an examination of causal directions and reciprocal relationships. Fourth, an assessment of virtues at both individual and hospital levels would permit an exploration of the links across levels of analysis. Finally, future research might fruitfully consider efforts to increase individual and organizational virtues to first see whether they were successful, and if so, had measurable effects on individual and organizational performance. 


\section{References}

Bailit, J. L., Weisberger, A., \& Knotek, J. (205) Resident job satisfaction and quality of life before and after work hours reform, Journal of Reproductive Medicine, 50, 649-652.

Baker, W., Cross, R., \& Wooten, M. (2003) Positive organizational network analysis and energizing relationships. In K. S, Cameron, J. E. Dutton, \& R. E. Quinn (eds.) Positive organizational scholarship. San Francisco: BerrettKoehler. Pp. 328-342.

Bakker, A. B. (2008) Building engagement in the workplace. In R. J. Burke \& C. L. Cooper (eds.) The peak performing organization. London: Routledge. In press.

Bateman, T. S., \& Crant, J. M., (1993) The proactive component of organizational behavior: A measure and correlates, Journal of Organizational Behavior, 14, 103-118

Becherer, R. C., \& Maurer, J. G. (1999) The proactive personality disposition and entrepreneurial behavior among small company presidents, Journal of Small Business Management, 38, 28-36.

Brown, K.W., \& Ryan, R. M. (2001) The benefits of being present: Mindfulness and its role in psychological well-being, Journal of Personality and Social Psychology, 84, 822-848.

Burbeck, R., Coomber, S., Robinson, S. M., \& Todd, C. (2002) Occupational stress in consultants in accident and emergency medicine: A national survey of levels of stress at wok, Emergency Medicine Journal, 19, 234-238.

Burke, R. J. (1996) Stress, satisfaction and militancy among Canadian physicians: a longitudinal examination, Social Science and Medicine, 43, 517524.

Burke, R. J., (1991) Early work and career experiences of female and male managers: Reasons for optimism? Canadian Journal of Administrative Sciences, 8, 224-232.

Burke, R. J. (1990) Sources of satisfaction and stress among Canadian physicians, Psychological Reports, 67, 1335-1344.

Cameron, K. S., Dutton, J., E., \& Quinn, R. E. (2003) Positive organizational scholarship, San Francisco: Berrett-Koehler.

Carlson, D., Kacmar, J., \& Williams, L., (2000) Construction and initial validation of a multi-dimensional measure of work-family conflict, Journal of Vocational Behavior, 56, 249-278.

Carr, P. L., Ash, A. S., Friedman, R. H., Szalacha, L., Barnett, R. C., Palepuy, A., \& Moskowitz, M. M. (2000) Faculty perceptions of gender discrimination and sexual harassment in academic medicine, Annals of Internal Medicine, 1342, 889-89. 
Carver, C. S. (1998) Resilience and thriving: Issues, models and linkages, Journal of social Issues. 54, 245-266.

Chambers, R., Wall, D., \& Campbell, I. (1995) Stresses, coping mechanisms and job satisfaction in general practitioner registrars, British Journal of General Practice, 46, 343-346

Cooper, C. L., Rout, U., \& Faragher, B. (1989) Mental health, job satisfaction, and job stress among general practitioners, British Medical Journal, 11, 366370.

Crant, J. M. (2000) Proactive behavior in organizations, Journal of Management, 26, 435-462.

Crant, J. M. (1996) The proactive personality scale as a predictor of entrepreneurial intention, Journal of Small Business Management, 34, 42-49.

Crant, J. M. (1995) The proactive personality scale and objective job performance among real estate agents, Journal of Applied Psychology, 80, 532-537.

Crant, J. M. \& Bateman, T.S.(2000) Charismatic leadership viewed from above: The impact of proactive personality. Journal of Organizational Behavior, 121, 63-75.

Defoe, D. M., Power, M., Holzman, G. B., Carpentieri, A., \& Schulkin, J. (2001) Long hours and little sleep: Work schedules of residents in obstetrics and gynecology, Obstetrics and Gynecology, 97, 1015-1018.

Diener, E., Emmons, R. A., Larsen, R. J., \& Griffin, S,. (1985) The Satisfaction with Life Scale, Journal of Personality Assessment, 49, 71-75.

Eisenberger, R., (1992) Learned industriousness, Psychological Review, 99, 248-267.

Emmons, R. A. (2003) Acts of gratitude in organizations. In K. S. Cameron, J. E. Dutton \& R., E., Quinn (eds,) Positive organizational scholarship. San Francisco: Berret-Koehler. pp. 81-93.

Emmons, R. A., \& McCullough, M. E. (2003) Counting blessings versus burdens: An experimental investigation of gratitude and subjective well-being, in daily life, Journal of Personality and Social Psychology, 84, 377-389.

Emmons, R. A., \& Crumpler, C. A. (2000) Gratitude as a human strength: Appraising the evidence, Journal of Social and Clinical Psychology, 19, 56-69.

Fredrickson, B. L., (2003a) Positive emotions and upward spirals in organizations. In K. S. Cameron, J. E. Dutton \& R. E. Quinn (eds). Positive organizational scholarship. San Francisco: Berrett-Koehler. pp.161-175.

Fredrickson, B. L. (2003b) The value of positive emotions, American Scientist, 91, 330-335.

Fredrickson, B. L. (2001) The role of positive emotions in positive psychology: The broaden-and-build theory of positive emotions, American Psychologist, 56, 218-226. 
Fredrickson, B. L. \& Losada, M. F. (2005) Positive affect and the complex dynamics of human flourishing, American Psychologist, 60, 678-686.

Fredrickson, B. L. \& Branigan, C. A. (2005) Positive emotions broaden the scope of attention and thought-action repertoires, Cognition and Emotion, 19, 313-332.

Fredrickson, B. L., \& Joiner, T. (2002) Positive emotions trigger upward spirals toward emotional well-being, Psychological Science, 13, 172-175.

Garza, J. A., Schneider, K. M., Promecene, P., \& Monga, M. (2004) Burnout in residency: A statewide study, Southern Medical Journal, 97, 1171-1173.

Golub, J. S., Weiss, P. S., Ramesh, A. K., Ossoff, R. H., \& Johns, M. M. (2007) Burnout in residents of otolaryngology-head and neck surgery: A national inquiry into the health of residency training, Academic Medicine, 82, 596-601.

Greenhaus, J. H., Parasuraman, S., \& Wormley, W. (1990) Organizational experiences and career success among black and white managers, Academy of Management Journal, 33, 6.

Janus, K., Amelung, V. E., Gaitanides, M., \& Schwartz, F., W. (2007) German physicians "on strike" -shedding light on the roots of physician dissatisfaction, Health Policy, 82, 357-365.

Kirkman, B. L., \& Rosen, G. (1999) Beyond self-management: Antecedents and consequences of team empowerment, Academy of Management Journal, 42, 58-74.

Kofodimos, J. (1993) Balancing act. San Francisco: Jossey-Bass.

Luthans, F. (2002) Positive organizational behavior: Developing and managing psychological strengths, Academy of Management Executive, 16, 57-72.

Luthans, F., Youssef, C. M., \& Avolio, B. J. (2007) Psychological capital. New York: Oxford University Press.

Luthans, F., Avolio, B. J., Avey, J. B., \& Norman, S. M. (2007) Positive psychological capital: Measurement and relationship with performance and satisfaction, Personnel Psychology, 60, 541-572.

Luthans, F., Vogelgesang, G. F., \& Lester, P. B. (2006) Developing the psychological capital of resiliency, Human Resources Development Review, 5, 25-44.

Luthans, F., Avery, J. B., Avolio, B. J., Norman, S. M., \& Combs, G. M. (2006) Psychological capital development: Towards a micro-intervention, Journal of Organizational Behavior, 27, 387-393.

McCullough, M. E., Emmons, R. A., \& Tsang, J. A. (2002) The grateful disposition: A conceptual and empirical topography, Journal of Social and Personality Psychology, 82, 112-127.

Murray, A., Montgomery, J. E., Chang, H., Rogers, W. H., Inui, T., \& Safran,, D. G. (2001) Doctor discontent: A comparison of physician satisfaction in different delivery system settings, 1986 and 1997, Journal of General Internal Medicine, 16, 452-459. 
Nelson, D. L., \& Cooper, C. L. (2007) Positive organizational behavior: Accentuating the positive at work. Thousand Oaks, CA: Sage Publications.

Overwalle, F. V., Mervielde, I., \& de Schuyter, J. (1995) Structural modeling of the relationship between attributional dimensions, emotions, and performance of college freshmen, Cognition and Emotion, 9, 59-85.

Ozyurt, A., Hayran, O., \& Sur, H. (2006) Predictors of burnout and job satisfaction among Turkish physicians, Quarterly Journal of Medicine, 99, 161169.

Parker, S. K. (1998) Enhancing role breadth self-efficacy: The roles of job enrichment and other organizational interventions, Journal of Applied Psychology, 83, 835-852.

Peterson, C. (2000) The future of optimism. American Psychologist, 55, 44-55.

Quinn, R. P., \& Shepard, L. J., (1974) The 1972-1973 Quality of Employment Survey. Ann Arbor, MI: Institute for Social research, University of Michigan.

Rout, U., \& Rout, J. K. (1994) Job satisfaction, mental health and job stress among general practitioners before and after the new contract - a comparative study, Family Practice, 11, 300-306.

Ryan, R. M., \& Frederick, C. M. (1997) On energy, personality, and health: Subjective vitality as a dynamic reflection of well-being, Journal of Personality, 65, 529-565.

Schaufeli, W. B., \& Bakker, a. B. (2004) Job demands, job resources and their relationship with burnout and engagement: A multi-sample study, Journal of Organizational Behavior, 25, 293-315.

Schaufeli, W. B., Salanova, M., Gonzalez-Roma, V., \& Bakker, a. B. (2002) The measurement of engagement and burnout: $A$ confirmative analytic approach, Journal of Happiness Studies, 3, 71-92.

Scheier, M. F., \& Carver, C. S. (1992) Effects of optimism on psychological and physical well-being: Theoretical overview and empirical update, Cognitive Therapy and Research, 16, 203-228.

Scheier, M. F., \& Carver, C, S. (1985) Optimism, coping, and health: Assessment and implications of generalized outcome expectancies, Health Psychology, 5, 219-247.

Scheier, M. F., \& Carver, C. S. (1987) Dispositional optimism and physical wellbeing: The influence of generalized expectancies on health, Journal of Personality, 55, 169-210.

Seibert, S. E., Crant, J. M., \& Kraimer, M. L. (1999) Proactive personality and career success, Journal of Applied Psychology, 84, 416-427.

Seligman, M. E. P. (1998) Learned optimism. New York:

Seligman, M. E. P. (1991) Learned optimism. New York: Knopf.

Seligman, M. E. P., \& Csikszentmihalyi, M., (2000) Positive psychology: An introduction, American Psychologist, 55, 5-14. 
Shirom, A. (2003) Feeling vigorous at work? The construct of vigor and the study of positive affect in organizations. In D. Ganster \& P. L. Perrewe (eds.) Research in organizational stress and well-being. Vol, 3. Greenwich, CT: JAI Press. pp. 135-165.

Simpson, L. A., \& Grant, L. (1991) Sources and magnitude of job stress among physicians, Journal of Behavioral Medicine, 14, 27-42,

Snyder, C. R. (1995) Conceptualizing, measuring, and nurturing hope, Journal of Counseling and Development, 73, 355-360.

Snyder, C. R. (1994) The psychology of hope: You can get there from here. New York: Free Press.

Snyder, C. R., \& Lopez, S. (2002) Handbook of positive psychology. Oxford: Oxford University Press.

Sutherland, V. J., \& Cooper, C. L., (1992) Job stress, satisfaction, and mental health among general practitioners before and after introduction of a new contract, British Medical Journal, 304, 1545-1548.

Tugade, M., M. \& Fredrickson, B. L. (2004) Resilient individuals can use positive emotions to bounce back from negative emotional experiences, Journal of Personality and Social Psychology, 86, 320-333.

Walker, L. J., \& Pitts, R. C.(1998) Naturalistic conceptions of moral maturity, Developmental Psychology, 34, 403-419.

Youssef, C. M., \& Luthans, F. (2007) Positive organizational behavior in the workplace: The impact of hope, optimism, and resilience, Journal of Management, 33, 774-8900. 